\title{
Toponymic politics and the symbolic landscapes of Minsk, Belarus
}

\author{
Sergei BASIK, Dzmitry RAHAUTSOU
}

\begin{abstract}
Recently, within the theoretical and methodological framework of critical human geography, the main focus of the toponymic research has been redirected from the traditional linguistic and socio-onomastic methods towards a critical analysis of the spatial politics of naming and the studies of the socio-political role of the place names as the components of the symbolic landscape. The toponymic politics of (re)naming the streets and other elements of the urban landscape has been a valuable tool for the political regimes to legitimate their symbolic power. This paper aims to analyze the relationships between the political power, the toponymic practices, and the symbolic landscapes on the example of the eclectic toponymic space of the city of Minsk, Belarus, from a semiotic perspective through the prism of the critical place names studies approach and the theoretical concept of toponymic identity. Using cartographic and archival research, on-site urban observations as well as comparative analysis, the in-depth case study reveals that the toponymic system of the Belarusian capital city consists of several elements which connect to an assortment of the symbolic spatial strategies of nationbuilding adopted by the governing authorities. The findings indicate that the urban toponymic landscape and the toponymic identities of the city of Minsk are symbolically motivated, and the heterogeneity of the contemporary urban toponymic system reflects actual political agendas of the past and current political regimes.
\end{abstract}

Keywords: toponymic politics, symbolic landscapes, critical toponymy, toponymic identity, Minsk, Belarus

\section{Introduction}

The development of the modern system of the political symbols in Belarus takes place in a protracted period of socio-economic and political transition. The symbolism associated with the socio-political sphere is subject to alteration, which is especially intensive during the periods of political and economic transformations in society. A significant characteristic of the symbolic system of Belarus is the presence of the unequal layers of the pre-Soviet symbols, the symbols of the Soviet period, and the symbolic segment of the period of independence. Despite the apparent dominance of the symbolic baggage of the Soviet era, it is possible to foresee some changes in the degree of influence and importance of the Soviet tradition in Belarusian symbolic politics.

Furthermore, there is a process of the new national political symbols formation associated with the development of Belarus as an independent state. Notably, the content of the symbolic politics reflects in the urban toponymic system of the country's capital, the city of Minsk. Within the framework of the symbolic elements of the politics, toponyms along with political language and visual propaganda are the verbal symbols of the ideological space. Thus, the place names are a vital sign of the political reality absorbed by an ideological discourse (Nikolaev 2013). Besides, the toponymic landscape is an essential element of national memory and identity (Azaryahu 2012, p. 397).

DOI: https://doi.org/10.33542/GC2019-2-02 
The modification of the socialist and post-socialist toponymic landscapes by the governing authorities have been considered by scholars from various theoretical and methodological points of view. However, there is an unexplored segment in the contemporary studies of the toponymic landscapes of Minsk as much less is known about the connections between the Belarusian toponymic politics, the toponymic identities, and the toponymic practices as the symbolic spatial strategies of nation-building in Belarus. Applying a sophisticated semiotic approach through the lens of the theory of critical toponymy (Vuolteenaho and Berg 2009, Rose-Redwood et al. 2010) and the theoretical concept of toponymic identity (Kostanski 2009, Kostanski 2016), this paper aims to address this research gap.

\section{Theoretical background}

The political sphere of modern society manifestly includes the sum of symbols expressing the ideological meaning and purpose of the existence of the political community. A symbol is a substantial identity of things and ideas, entities, and phenomena, according to the Russian philosopher Losev (1993). In the traditions of the Tartu-Moscow school of semiotics, which work as a theoretical base of this paper, a fundamental element of the semiosphere, a symbol, acts as a mediator between the semiotic and non-semiotic reality (Lotman 2002, pp. 211-225). Historically, the urban street names serve as a useful political tool "for inserting the official version of the past into the semiosphere" (Azaryahu 1990, p. 33). Moreover, they possess "the sociosemiotic power" (Azaryahu 1996, p. 328), and the entire toponymic system bears an ideological load of the past and current political regimes. Consequently, toponyms express "the commemorative priorities and hegemonic discourses of previous periods" (Rose-Redwood et al. 2010, p. 460). In a broader sense, the toponymic practices of place naming and renaming are inevitably linked to the contested relationships between the governing authorities and society, and this reflects in the urban semiosphere.

In urban cultural landscapes, toponyms act as the "power-charged semiotic dynamos for making meaning about places" (Vuolteenaho and Berg 2009, p. 7). Accordingly, a place name can acquire a specific semantic and ideological content under the influence of the symbolic policy of a particular political elite in a certain period. Traditionally, the various political regimes use toponyms as memorial symbols to justify and legitimize their dominance. As a segment of public memory, the toponymic landscape is not only a component of historical heritage: naming and re-naming of urban space are the strategies of power implemented in the appropriate place (Raento and Watson 2000), and these strategies instantly affect everyday life, language, and space (Azaryahu 1996). Consequently, an artificial collective identity can be created, applied, and preserved in space using various naming technologies (and their combinations) such as toponymic cleansing, founding, restoring, and promoting (Giraut and Houssay-Holzschuch 2016).

Symbolically and emotionally, toponyms are an expression of the people's everyday communication, psychological state, and perception of the world (Ryliuk 1999). Therefore, there is a connection to the theory of toponymic attachment - "positive or negative association individuals and groups make with real or imagined toponyms" (Kostanski 2016, p. 412). The vital aspect within the framework of toponymic attachment is that the place names can symbolize an emotional attachment of people to a place (a positive or negative). One of the components in this theory is a concept of toponymic identity which is "a construct through which people link to history, allocate their memories, assert cultural ideologies, assist in expressing personal and community emotions and determine what is culturally important" (Kostanski and Puzey 2014, p. 1217). Accordingly, toponyms hold multiple meanings for many purposes, and personal or community identity can be linked to the place names in a similar way to which it can be connected to places. Importantly, a toponym can concurrently hold various identities separate to those identities held by the place (Kostanski 2009, Kostanski 2016). This function of 
toponym is a possible prospective point for understanding the relationships between the processes of transformations of urban toponymic systems during the periods of socio-political instability and can elaborate symbolic preservation or destruction of the specific place names in a particular place.

According to Azaryahu (1990), an urban toponymic system creates a "city-text" as a representation of the past. Above all, a city-text can include other elements of the urban landscape (such as the monuments and statues), and it appears as "a set of everyday political symbols through which collective memory is constructed in an urban space" (Palonen 2008, p. 229). However, one of the specific features of the urban place names complex is that the former strata are not always completely erased and disappeared but instead coexisted with the new ones. Therefore, a city-text is a palimpsest, which is not only recorded continuously "and rewritten by many "authors" but also interpreted in its way by different readers" (Rose-Redwood et al. 2017a).

Instead of the traditional onomastic etymological investigations, a critical approach to the analysis of the spatial politics of naming emerged in recent decades as a contemporary direction in toponymic studies (Vuolteenaho and Berg 2009, Rose-Redwood et al. 2010). The contested relationships between the landscapes, people, identity, and power, which reflected in various toponymic metamorphoses in socialist and post-socialist states, have been an object of a sizeable body of the toponymic scholarship. This significant stratum of the recent place names studies includes, to name but a few, the following works focused on different countries: Romania - Light et al. (2002), Light (2004), Light and Young (2014), Creţan and Matthews (2016), Erőss (2017); Armenia - Saparov (2003); Russia - Gill (2005), Marin (2012); Hungary - Palonen (2008); Croatia - Šakaja and Stanič (2011), Crljenko (2012); several Central and Eastern European states including post-socialist Poland, Czechia, Slovenia, Bosnia and Herzegovina, and Croatia - Stiperski et al. (2011); Serbia - Rajić (2012); East Germany Azaryahu (2012), Vuolteenaho and Puzey (2017); Slovakia - Bucher et al. (2013), Chloupek (2019); Poland - Drozdzewski (2014); Azerbaijan - Saparov (2017); Czechia and Poland Mácha, Lassak, and Krtička (2018); Ukraine - Gnatiuk (2018). Much of this research concentrate on the urban toponyms, some of the studies direct towards the analysis of the names of towns and physiographical objects. However, despite the extensive geographical coverage of cases from Germany to Azerbaijan, Belarusian toponymic material has been on the periphery of the international critical scholars' attention though Belarus was mentioned recently by Light and Young (2017).

Naturally, the political aspects of the toponymic system of Minsk have attracted the attention of the contemporary Belarusian scholars who addressed the issues related to the place names to varying degrees depends on scientific interests. For instance, Titarenko $(2008,2011)$, focused research on the sociological aspects of toponyms in Minsk as the component of Belarusian cultural identity politics. Satsukevich $(2010,2013)$ analyzed the process of the historical development of the urban toponymic system and naming/renaming patterns in Minsk in $20^{\text {th }}-21^{\text {st }}$ century. From the historical perspective, Kazakevich (2011) discussed the dynamics of the toponymic transformations in the capital of Belarus in the 1990s - 2000s concerning the Soviet legacy in the urban landscape. Kapylou and Lipnitskaya (2014) described the problems of the place names standardization in Belarus from the point of view of onomastics. Gordziejew (2017), in his historical study of the urban place names, connected Belarusian urban toponymy to the discourse analysis. Urban place names, as a critical element of the semiotic space of Minsk, were considered in the framework of cultural studies by Sokolova (2017). Finally, Basik and Rogovtsov (2017) implemented some elements of the critical toponymy approach to discuss national political symbolism using various regional toponymic examples from Belarus, including some urban toponyms of Minsk.

Though the Belarusian scholarship in the fields related to political toponymy has been growing recently, the numerous vital questions related to the modern toponymic system of 
Minsk remained unanswered. For instance, it is essential to find the connections between the various spatial techniques and strategies used by authorities to insert active political agendas of the regime into the urban toponymic space and the symbolic elements of the semiosphere of the capital of Belarus. Thus, the goal of this paper is to examine a contemporary system of the toponymic practices as a political spatial strategy that alters the symbolic landscapes of Minsk as a capital of the independent state and constructs the basis for the Belarusian national identity through the toponymic identities.

\section{Methods}

The object of this research is the modern toponymic system of Minsk, the capital and the largest city in the Republic of Belarus with a population of 1,992,700 (National Statistical Committee of the Republic of Belarus 2019). The study covers the city in its administrative borders with an area of $348,85 \mathrm{~km}^{2}$ (Minsk City Executive Committee 2019). In this in-depth case study based on the critical toponymy approach, we implemented a combination of various methods including cartographic and archival research, which are regarded as "essential resources" in methodological context (Rose-Redwood et al. 2017b), as well as in situ observations. We focused primarily on the toponyms in synchronic perspective and applied elements of the quantitative interpretation, the comparative analysis, and the onomastic methods.

For this study, we analyzed the list of current 1336 toponyms of Minsk (Minsk City Agency on State Registration and Land Cadastre 2019). The complete list of these place names comprises of three onomastic classes of toponyms: hodonyms, the names of the streets, avenues, boulevards, lanes, passages; agoronyms, the names of the squares; drymonyms, the names of the parks and parkettes. The names of the natural objects within the city boundaries were not considered.

All place names in this study were classified according to the selected criteria based on their semantics through the analysis of cartographic, historical archival, onomatological, and lexicological materials. Consequently, we distinguished six semantic naming categories: 1) persons; 2) history; 3) geography; 4) professional activities, factories, institutions; 5) descriptive and euphonic; 6) other. This classification is comparable to the taxonomy utilized for the place names of Minsk by Kazakevich (2011). However, our grouping of toponyms differs significantly from the Kazakevich's taxonomy as we applied the fragments of the classification framework used by Stiperski et al. (2011) and made some substantial modifications. Accordingly, we were able to distinguish more toponymic taxonomic units which are a result of the significant changes in the Minsk toponymic system since 2009 due to the process of the rapid city growing, specifics of the regional place names, and the purpose of this paper. A new category of "Descriptive and euphonic" toponyms included in the classification due to a substantial number of this type of place names in Minsk. Specific categories, in particular, the most proportionally significant, were divided into groups concerning the relevant historical context and into subgroups according to the historical or spatial denotations of toponyms.

The limitations of this study include a small percentage of toponyms (about 1.5\%) that might be classified differently and inserted into more than one taxonomic unit. As Chloupek (2019, p.72) pointed out, the elements of the communist city-texts are harder to interpret "because their meanings are often more nebulous and open to multiple interpretations." For example, often the leaders and the active members of the communist party took part in WWII, so the associated with these persons commemorative place names can be included either in the World War II subgroup or in Soviet communist leaders, heroes, and personalities subgroup. In such cases, we considered the most crucial role or accomplishments of the person as a specific critical characteristic. The same methodological solution was implemented by the scholars (Kazakevich 2011, Stiperski et al. 2011, Bucher at al. 2013) for the polysemantic commemorative toponyms that might be placed in two or more taxonomic units. 


\section{Results and discussion}

The taxonomic grouping of the urban place names by semantics shows the heterogeneity of the contemporary toponymic system in Minsk. First, we will consider the categories of toponyms and their taxonomic entities based on this classification. Then, we will be interpreting and discussing the results obtained.

All place names in the first category, "Persons," are commemorative by nature: they honor and immortalize remembrance about a particular personality. This toponymic segment is the most substantial category of the place names acquiring $39 \%$ of all toponyms. Due to this characteristic, the category was divided into three groups reflecting the main historical layers of toponyms (pre-Soviet, Soviet, post-Soviet) and a geographical context (Tab. 1). Also, the two largest groups split into seven subgroups reflecting Belarusian persons and persons represented Russian (pre-Soviet) or Soviet realm. As can be seen, the Soviet group, which is the largest segment of the "Persons" category, is representing more than a quarter of all toponyms in Minsk (25.8\%). Moreover, the subgroup World War II is the most significant taxonomic unit among all subgroups and some groups in other categories: it comprises of $11 \%$ of all toponyms in Minsk and almost one-third of the names in this category.

Tab. 1. The structure of the semantic category "Persons"

\begin{tabular}{|c|c|c|c|c|}
\hline Groups & Subgroups & Toponymic examples & $\begin{array}{c}\text { Proportion, } \\
\text { all toponyms (\%) }\end{array}$ & $\begin{array}{c}\text { Proportion, } \\
\text { within category }(\%)\end{array}$ \\
\hline \multirow{3}{*}{ Pre-Soviet } & $\begin{array}{c}\text { Belarusian culture, } \\
\text { arts, science }\end{array}$ & $\begin{array}{l}\text { Vulica Tsjapinskaha } \\
\text { (Tsjapinski Street) }\end{array}$ & 2.8 & 7.3 \\
\hline & $\begin{array}{c}\text { Russian culture, } \\
\text { arts, science }\end{array}$ & $\begin{array}{l}\text { Vulica Pushkina } \\
\text { (Pushkin Street) }\end{array}$ & 6.4 & 16.3 \\
\hline & $\begin{array}{l}\text { Personalities, } \\
\text { generals, heroes in } \\
\text { the Russian realm }\end{array}$ & $\begin{array}{l}\text { Vulica Kuz'my Minina } \\
\text { (Kuz'ma Minin Street) }\end{array}$ & 2.5 & 6.5 \\
\hline \multirow[t]{4}{*}{ Soviet } & $\begin{array}{c}\text { Communist leaders } \\
\text { and personalities }\end{array}$ & $\begin{array}{l}\text { Vulica Lienina } \\
\text { (Lenin Street) }\end{array}$ & 5.7 & 14.5 \\
\hline & World War II & $\begin{array}{c}\text { Vulica Marshala Losika } \\
\text { (Marshal Losik Street) }\end{array}$ & 11.0 & 28.2 \\
\hline & $\begin{array}{c}\text { Belarusian culture, } \\
\text { arts, science }\end{array}$ & \begin{tabular}{|c|} 
Vulica Yakuba Kolasa \\
(Yakub Kolas Street)
\end{tabular} & 6.1 & 15.7 \\
\hline & $\begin{array}{c}\text { Soviet culture, arts, } \\
\text { science }\end{array}$ & $\begin{array}{l}\text { Vulica Majakoūskaha } \\
\text { (Majakoūski Street) }\end{array}$ & 3.0 & 7.7 \\
\hline \multicolumn{2}{|c|}{ Post-Soviet } & \begin{tabular}{|c|} 
Park Mikhaila Paūlava \\
(Mikhail Paūlaū Park)
\end{tabular} & 0.4 & 0.9 \\
\hline \multicolumn{2}{|c|}{ International } & $\begin{array}{l}\text { Vulica Fučeka } \\
\text { (Fuček Street) }\end{array}$ & 1.1 & 2.9 \\
\hline \multicolumn{3}{|c|}{ Total } & 39.0 & 100.0 \\
\hline
\end{tabular}

The second and the third subgroups in the category by the number of toponyms in Minsk are respectively the pre-Soviet Russian culture $(6.4 \%)$ and the Soviet Belarusian culture $(6.1 \%)$. The substantial number of the commemorative place names also includes Communist leaders and personalities sub-group (5.4\% of all toponyms). Interestingly, the post-Soviet group and international groups are particularly trivial (only $1.5 \%$ of toponyms in Minsk).

The "Geography" toponymic category is the second largest in Minsk: it includes 32.5\% of all toponyms in the city (Tab. 2). There are eight groups in this category, and the subgroups were not distinguished. The most substantial proportion of the place names in this category consists of two groups: the Belarusian place names and the Rural settlements, land tenures, natural areas, amalgamated with Minsk. Both groups conceive $19.4 \%$ of the toponyms in 
Minsk or almost $60 \%$ of toponyms in this category. The third-largest group in this category is the Russian place names (5.6\% of all toponyms in Minsk). The smallest proportion of the names represents the toponyms outside the former USSR (just $0.5 \%$ of this category). Finally, the toponyms semantically motivated by the physical and locational characteristics of the place include three groups where the Locational and spatial group comprises $2.1 \%$ of the place names in Minsk.

Tab. 2. The structure of the semantic category "Geography"

\begin{tabular}{|c|c|c|c|}
\hline Groups & Toponymic examples & $\begin{array}{c}\text { Proportion, } \\
\text { all toponyms (\%) }\end{array}$ & $\begin{array}{c}\text { Proportion, } \\
\text { within category (\%) }\end{array}$ \\
\hline $\begin{array}{c}\text { Rural settlements, land tenures, natural ar- } \\
\text { eas amalgamated with Minsk }\end{array}$ & $\begin{array}{c}\text { Vulica Shabany } \\
\text { (Shabany Street) }\end{array}$ & 9.1 & 28.1 \\
\hline Belarusian place names & $\begin{array}{c}\text { Vulica Polackaja } \\
\text { (Polack Street) }\end{array}$ & 10.3 & 31.8 \\
\hline Russian place names & $\begin{array}{c}\text { Vulica Tomskaja } \\
\text { (Tomsk Street) }\end{array}$ & 5.6 & 17.3 \\
\hline Former USSR place names & $\begin{array}{c}\text { Vulica Tallinnskaja } \\
\text { (Tallinn Street) }\end{array}$ & 2.2 & 6.7 \\
\hline The rest of the world place names & $\begin{array}{c}\text { Plošča Banhalor } \\
\text { (Bangalore Square) }\end{array}$ & 0.2 & 4.8 \\
\hline Plants and vegetation type & $\begin{array}{c}\text { Vulica Sasnovaja } \\
\text { (Pine Street) }\end{array}$ & 1.6 & 4.4 \\
\hline Other physiographic toponyms & $\begin{array}{c}\text { Vulica Balotnaja } \\
\text { (Swamp Street) }\end{array}$ & 1.4 & 6.4 \\
\hline Locational and spatial & $\begin{array}{c}\text { Vulica Central'naja } \\
\text { (Central Street) }\end{array}$ & 2.1 & 100.0 \\
\hline \multicolumn{2}{|c}{ Total } & 32.5 & \\
\hline
\end{tabular}

The structure of the semantic category "History" is quite simple because this category represents only $9 \%$ of all toponyms in Minsk: there are two groups, and the largest group of Ideologemes, dates, national symbols consists of two historical sub-groups (Tab. 3). The Soviet sub-group includes $5.3 \%$ of the toponyms in Minsk or more than half of toponyms in this category. One more critical point that again, as for the category of "Persons," the post-Soviet segment is negligible (only $0.4 \%$ of Minsk's place names). The Reconstructed and pre-Soviet names include various toponyms which comprise $3.3 \%$ of the toponyms in the city.

Tab. 3. The structure of the semantic category "History"

\begin{tabular}{|c|c|c|c|c|}
\hline Groups & Subgroups & Toponymic examples & $\begin{array}{c}\text { Proportion, } \\
\text { all toponyms (\%) }\end{array}$ & $\begin{array}{c}\text { Proportion, } \\
\text { within category (\%) }\end{array}$ \\
\hline \multirow{2}{*}{$\begin{array}{c}\text { Ideologemes, dates, } \\
\text { national symbols }\end{array}$} & Soviet & $\begin{array}{c}\text { Vulica Savieckaja } \\
\text { (Soviet Street) }\end{array}$ & 5.3 & 58.7 \\
\cline { 2 - 5 } & Post-Soviet & $\begin{array}{c}\text { Praspiekt Niezaliežnasci } \\
\text { (Independence Avenue) }\end{array}$ & 0.4 & 4.1 \\
\hline Reconstructed and pre-Soviet names & $\begin{array}{c}\text { Vulica Zalataja Horka } \\
\text { (Golden Hill Street) }\end{array}$ & 3.3 & 37.2 \\
\hline \multicolumn{6}{|c|}{ Total } & 9.0 & 100.0 \\
\hline
\end{tabular}

The fourth category, "Professional activities, factories, institutions," is one of the single taxonomic units. Comprising $11.8 \%$ of all names in Minsk, this is one of the most artificial toponymic components of the urban semiosphere: Vulica Mantažnikaū (Installers Street), Vulica Inženiernaja (Engineering Street). 
"Descriptive and euphonic" toponyms include $6.7 \%$ of the cities place names. Usually, they have general, positive, or figurative meaning (Vulica Cihaja - Quiet Street, Vulica Radužnaja - Rainbow Street), and these place names are called hedonyms (Ryliuk 1999). A similar "poetic" group that provides "emotional load" was distinguished in Ukraine (Gnatiuk 2018). Finally, the "Other" category includes 1\% of unclassified toponyms in Minsk (for example, Vulica Vjalikamorskaja).

Based on the semantic analysis, the dominant in quantitative terms in the toponymic landscape of the capital of Belarus is the Soviet symbolic segment with the corresponding commemorative priorities: they acquire 38.9\% of toponyms in Minsk combining groups and subgroups in three categories of "Persons" (Soviet), "Geography" (Former USSR Place Names; Russian Place Names), "History" (Soviet ideologemes). Remarkably, Pospelov (1988), analyzing the place names of four cities of the Soviet Union (Moscow, Minsk, Donetsk, and Gorkiy), found that the toponymic space of these cities contains $33 \%$ of the same names, and the total number of repetitions of these Minsk toponyms at least at one of these cities is $70 \%$ of the list. Undoubtedly, the "toponymic unification" of public spaces, caused by the ideological orientation of the Soviet era, is one of the essential reasons for the state of contemporary toponyms in the Belarusian capital. The most rigid Soviet toponymic landscape located in the central part of the city: the names of Lenin, Sverdlov, Kirov and other communist leaders, the toponymic ideologemes such as Kamunistychnaja, Internacyjanal'naja, Savieckaja still dominate. Traditionally, in historical core areas of cities, the names of streets are "of first-rate importance" for the city authorities (Stiperski et al. 2011, p. 184).

The constant erasing and rewriting of the urban palimpsest by a political power clearly illustrate the story of the main avenue of Minsk, the symbolic "axis" of the city. The street was renamed 14 times in just over 200 years (Sokolova 2017, p. 90). It seems that it would be challenging to find the same number of the main avenue name's transformations among the European capital cities over the same period though some of them where renamed many times as well (Rajić 2012). At the moment, it is Independence Avenue, a new name created in 2005 as per the decree of the President of Belarus, but there is no guarantee that the name will not be erased and rewritten again in the future.

Therefore, the repeated rewriting of the toponymic palimpsest is based on the inscription of new "text" as well as erasing or reconstruction of the past layers. Some of the layers can be restored several times, depending on the commemorative priorities of the ruling political regime. For example, the name Vulica Savieckaja (re-)emerged three times in 1919, 1920, and 1944. The symbolic role of the "main" street in the urban semiosphere was clear for all political regimes, and they used simple hegemonic "top-down" practices of the construction of commemorative priorities based on their ideological or geopolitical preferences.

Among the "Soviet segment," the WWII component plays the most significant role. It includes not only $11 \%$ of Minsk toponyms that commemorate the persons but also the place names in other taxonomic units such as History with related to war connotations, abstract ideologemes, dates (Partyzanski Praspiekt - Partisan Avenue, Plošča Pieramohi - Victory Square). Though the Soviet toponymic legacy considered by Belarusian scholars as to the critical feature of the symbolic landscapes of Minsk (Kazakevich 2011, Sokolova 2017, Gordziejew 2017), we would like to focus on some new nuances. When Light and Young (2017) discussed the examples of toponymic continuity of the Soviet-era place names in Minsk, a contemporary agenda of the Belarusian political regime was mentioned as the main reason for the conservation of such place names. However, as a significant number of Soviet-era toponyms related to WWII, it also has strong references to the emotional trauma of the Belarusian people during the war were the nation lost up to one-third of the population (Basik 2019).

Furthermore, the city of Minsk was almost destroyed during the war and rebuilt afterward. Correspondingly, it reflects specific "emotional relationships" (Light and Young 2017, p. 199) 
between the ordinary people and toponyms based on the historical emotional trauma and represents "everyday spaces as the silent witnesses to trauma" (Drozdziewski, 2014, p. 77), creating favorable environment for the toponymic continuity. Moreover, relying on the toponymic identity that expresses the personal and collective memories about the national emotional trauma, the WWII commemorative strategy successfully emphasized by the authorities still plays a vital role in contemporary official toponymic (re)naming practices (Praspiekt Peramožcaū - Avenue of the Victors; Vulica Marshala Losika).

The lack of logic in the process of naming and a banal approach to the selection of new names in 1950s - 1970s created an awkward toponymic category of "Professional activities, factories, institutions." However, this toponymic segment continues to exist, as some recently created names reflect new realities and political trends. For example, toponym Vulica Pragrammistaū (Programmers Street) can express a politically and symbolically motivated goal of the modern "IT-country" construction in Belarus.

One more example of expressing the Belarusian national toponymic system includes the names Navukovaja (Scientific) and Pis'miennikaū (Writers) which are officially transliterated from Belarusian to the Russian language. This international principle of standardization for the bilingual states is a new trend in modern toponymic policies. As Kapylou and Lipnitskaya (2014) state, the translation of Russian into the Belarusian language has been a critical principle of urban toponymic transference (for instance, Ulica Oktjabr'skaja - Vulica Kastrychnickaja).

The amplification of the toponymic functions of local and regional place names is one of the typical characteristics of the post-Socialists states (Gnatiuk 2018). The expanding group of Belarusian toponyms encrypted into the toponymic system of Minsk is one more important direction in contemporary naming practices. In fact, in 1960s - 1970s the irrelevant to the locals Russian (in particular, Siberian) place names such as Bajkal'skaja, Anharskaja, Irkutskaja were implanted into the urban semiosphere forming an artificial toponymic identity separate from the identity of the place. Currently, the names of the Belarusian cities, rivers, rural settlements, land tenures, natural areas included in Minsk due to the expansion of the city create new national toponymic identity in the Belarusian capital, especially in the peripheral areas. The same naming strategy the authorities use for other urban objects (for instance, for new metro stations - Shejpichy, Pjarespa).

A symbolic toponymic eclecticism is a typical feature of the modern place names' system of Minsk. The lack of chronology is "a fundamental property of a city-text" - historical figures and events co-exist simultaneously (Azaryahu 1996, p. 327). As an illustration, recently, there is a growing number of names associated with Belarusian national culture, arts, traditions, and history. Though most of these place names located as clusters of toponyms in peripheral sections of the city, the Belarusian national toponymic trend is real. For instance, in the newly minted south-west neighborhood Brylievichi, Napoleon Orda Street (Belarusian 19 century artists) and Jan Čačot Street (Belarusian 19 century romantic poet) have the intersections with Dzjaržynski Avenue (Soviet political figure, a founder of the principal Soviet security agency NKVD/KGB). Oddly enough, the Minsk toponymic system contains both the names of the executioners and victims of Stalin's period. For example, Šaranhoviča Street (one of the organizers of the repressions in Soviet Byelorussiya in 1937) intersects with Maksim Harecki Street (a classic of the Belarusian literature who was killed during the repressions). These facts emphasize the heterogeneity of Minsk city-text with inscriptions of various, very often absolutely opposite, cultural and symbolic codes and toponymic identities.

With the acquisition of state sovereignty, new toponyms emerge in response to the international political agenda of the country and the process of globalization. For instance, two new city parks named in honor of Simon Bolivar and Hugo Chavez (Fig. 1) represent the close ties of the Belarusian political elite with Venezuela. At the same time, the name of Changchun Park not only reflects the sister city of Minsk but expresses the growing political connections with China. 


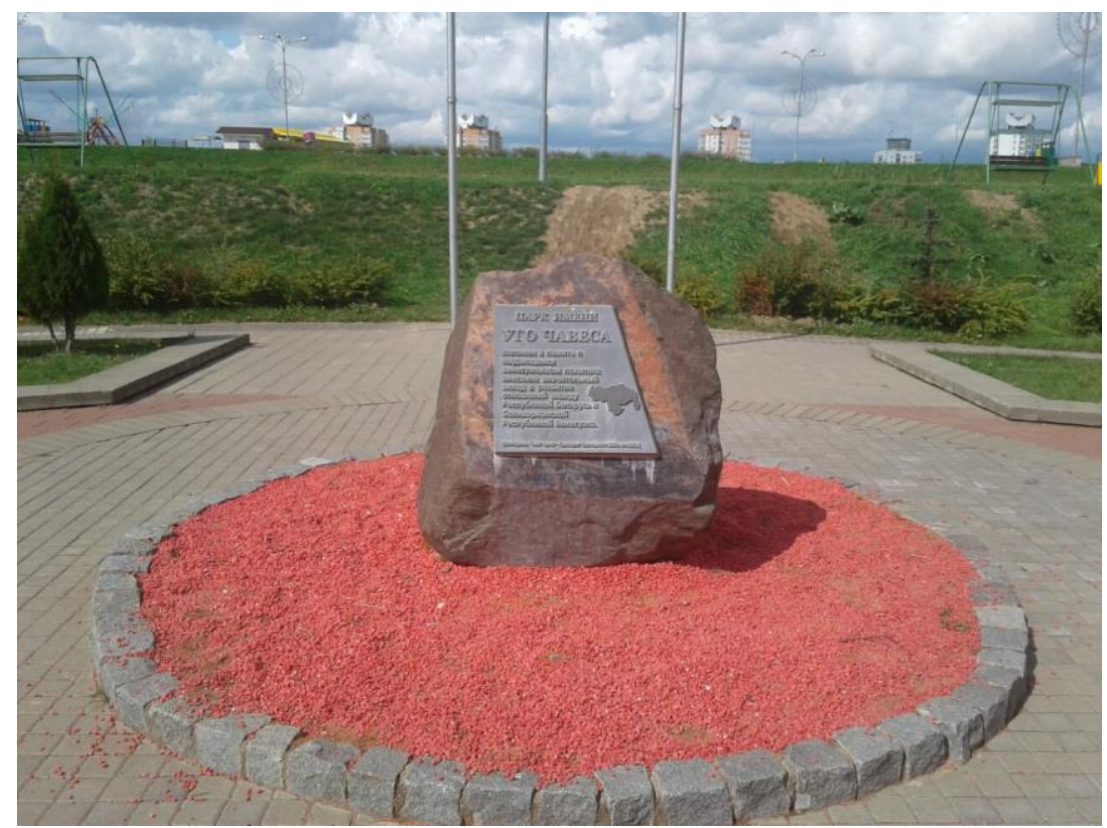

Fig. 1. A memorial plaque to commemorate the former president of Venezuela Hugo Chavez in Hugo Chavez Park. Minsk, Belarus; Source: Image by Andrej Berasneu

The internationalization of the semiotic landscape appears on the example of the emerging multifunctional residential and business complex "Minsk-World." There are different "quarters" in this complex such as "North America," "Southern Europe," "Asia," and, respectively, the names of the high-rise condominiums include such examples as "San Francisco," "Athens," and "Hong Kong." This sort of promotional toponymy is related to the processes of city branding and the toponymic commodification of urban space examined in recent years within the "second wave" of critical toponymic studies (Rose-Redwood et al. 2019). Though these examples are not related to the names of the streets, squares, and parks in Minsk, this international trend is expected in the broader toponymic landscape of the city shortly. For instance, one of the projected streets in this complex will be called Vulica Bjalhradskaja (Belgrade Street), which can be connected to the country of origin of the "Minsk-World" developers, a Serbian company.

One more critical modern element is the practice of Latin transliteration of the place names which establishes the political priority of Belarusian national toponymy and toponymic identity on the international stage. A positive example was the Latin duplication of the Belarusian Cyrillic names of the geographical objects in Minsk before the ice hockey world championship in 2014 (Basik and Rogovtsov 2017). At the same time, this can work as an element of the city branding with the goal of internalization of the urban landscape for the future commercialization of urban space.

Remarkably, the contemporary complex toponymic system of Minsk represents the various toponymic identities. The hegemonic toponymic practices based on the legitimization of ideology and political regime during the Soviet era generated a highly politicized toponymic component in Minsk. According to Chloupek (2019, p. 73), the liminal post-communist landscapes will continue to exist "as long as elements of the communist city-text are still viable as sources of political meaning." At the same time, some of the toponymic identities created during the Soviet period have an essential and deep emotional attachment for the locals and still play an essential role in the contemporary process of naming (WWII group of toponyms). 
New toponyms that commemorate Belarusian cultural heritage, as well as national and local place-names, form another segment of toponymic identities connected to the national cultural traditions, pre-Soviet history, and they can serve a possible base for "new" national identity. Though these place names are spatially stigmatized and moved toward the peripheral areas of the city, some examples of renaming in the central parts of Minsk also took place recently, for example, the reestablishment of the historical toponyms Vulica Zybickaja (Fig. 2) and Vulica Trajeckaja Nabieražnaja in 2010.

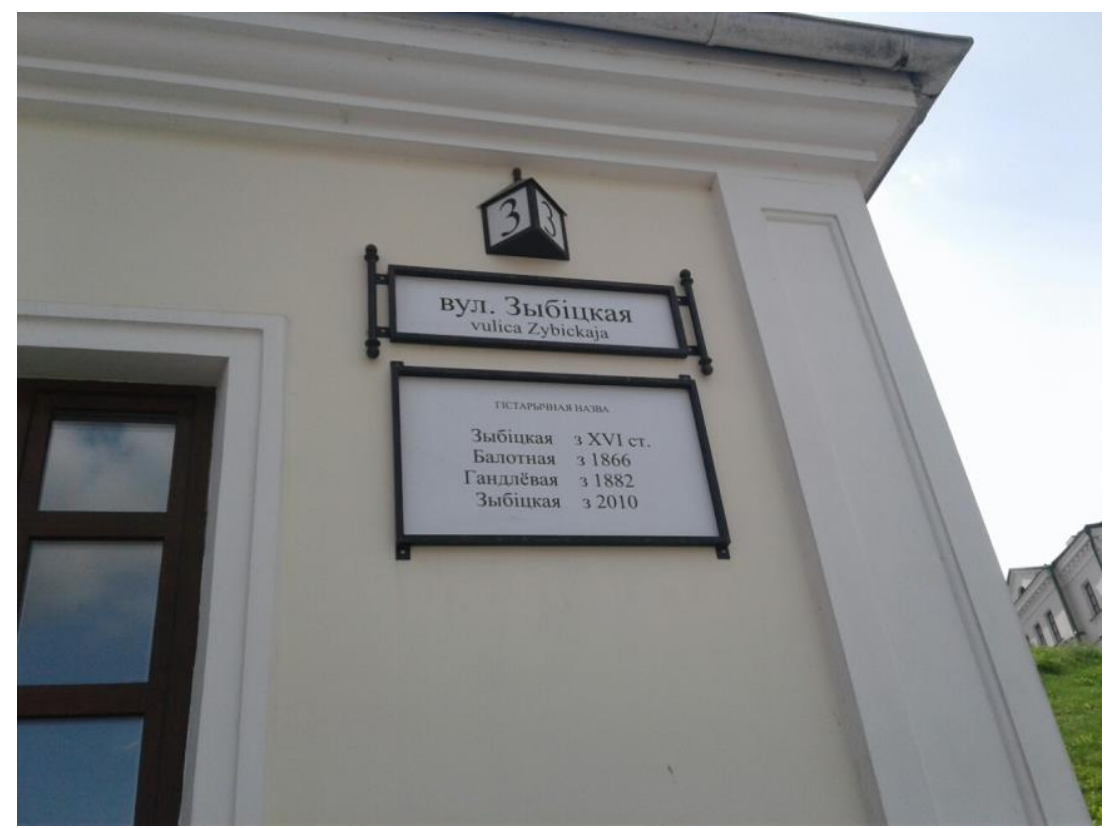

Fig. 2. Vulica Zybickaja and the list of the historical names of this street; Source: Image by Andrej Berasneu

Finally, some of the newly minted place names reflect either the international political agenda of the current government or the desired place of Minsk in the globalized world. Besides, independence and its symbols also become the evident type of the modern toponymic elements in Minsk (Independence Avenue, the Square of the National Flag).

As a result, in the same way as the modern national identity of Belarusians (Titarenko 2011), the toponymic identities of Minsk also can be described as "multifaceted." Moreover, the toponyms are connected to the process of the construction of Belarusian national identity by the authorities through the assortment of symbolic spatial strategies of nation-building. The situation of the symbolic coexistence of the various toponymic identities might be changed in the future through the process of natural change of generations in society, the gradual growth of the national consciousness of Belarusians, and, eventually, the crystallization of "new" national identity.

\section{Conclusions}

To sum up, this study is the first attempt to explore the contemporary toponymic politics and the place names system of Minsk, Belarus through the semiotic perspective applying the theory of critical toponymy and the conceptual theoretical approach of toponymic identity in order to analyze the symbolic landscapes and the role of political power in their transformations. Using different methods, including cartographic, archival, onomastic research, on-site urban observations, and comparative analysis, we develop and analyze a new semantic classification of the urban place names of Minsk with six categories of toponyms. The taxonomy 
reveals the dominance of the categories of "Persons" with WWII group as the most significant and "Geography" with emerging group reflected local and national Belarusian toponyms.

Further analysis discloses that a symbolic toponymic eclecticism of Minsk represents different toponymic identities, and there are actual connections between the symbolic landscape of the city and the political power. Consequently, we bring to light several modern symbolic spatial strategies of nation-building through the alteration of the toponymic system used by the Belarusian authorities in the late $20^{\text {th }}$ and the $21^{\text {st }}$ centuries:

1) ongoing WWII commemoration which is relying on the toponymic identity connected to the historical memories and the emotional trauma of the Belarusians;

2) conservation of the Soviet-era place names in the city core with the selective changes;

3) slight "belarusization" of the toponymic system through the transliteration of toponyms from Belarusian to the Russian language and creation of national toponymic identity based on the regional place names, historical nomenclature, and the commemoration of the Belarusian personalities in arts and science, mostly, in peripheral areas of the city with the sporadic changes in the city core;

4) attempts of internationalization of the place names system through the Latinization of Belarusian toponyms on the street signs;

5) the emergence of toponyms that reflect the international political agenda of the authorities;

6) city branding goals related to the commodification of urban space in a globalized world and the promotion of Belarus as a new IT hub;

7) the increasing role of the symbols of independence in the toponymic system that reflects a new political reality of independent Belarus.

Some potential directions of future critical research in political toponymy of Minsk and Belarus might include among others the following topics: a systematic investigation of the regional toponymic identities in the Belarusian toponymic palimpsest; an analysis of the Belarusian toponymic identities in connection to the ideological preferences and popularity among people; an exploration of the street signs as the elements of a symbolic landscape that represents the political agendas of the authorities in a bilingual country.

\section{References}

AZARYAHU, M. 1990: Renaming the past: changes in "city-text" in Germany and Austria 1945 - 1947. History and Memory, 2(2), 32-53.

AZARYAHU, M. 1996: The power of commemorative street names. Environment and Planning D: Society and Space, 1996, 14(3), 311-330. DOI: https://doi.org/10.1068/d14 0311.

AZARYAHU, M. 2012: Renaming the past in post-Nazi Germany: insights into the politics of street naming in Mannheim and Potsdam. Cultural Geographies, 19(3), 385-400. DOI: https://doi.org/10.1177/1474474011427267.

BASIK, S. 2019: The Political Life of Urban Streetscapes: Naming, Politics, and Place. Canadian Journal of Urban Research, 28(1), 65-66.

BASIK, S. N., ROGOVTSOV, D. A. 2017: The politics and practice of the toponymic nomination in the context of national political symbols of Belarus: theoretical and conceptual aspect. Vesnik of Yanka Kupala State University of Grodno. Series 1. History and Archeology. Philosophy. Political Science, 9(3), 116-123. [БАСИК С. Н., РОГОВЦОВ Д. А. 2017: Политика и практика топонимической номинации в контексте национальной политической символики Беларуси: теоретико-концептуальный аспект. Веснік Гродзенскага дзяржайнага ўніверсітэта ім. Я. Купалы. Серыя 1. Гісторыя. Філасофія. Паліталогія, 9(3), 116-123].

BUCHER, S., MATLOVIČ, R., LUKÁČOVÁ, A. et al. 2013: The perception of identity through urban toponyms in the regional cities of Slovakia. Anthropological Notebooks, 19(3), 23-40.

CHLOUPEK B. R. 2019: Post-communist city text in Košice, Slovakia as a liminal landscape. Miscellanea Geographica - Regional Studies on Development, 23(2), 71-75. DOI: https://doi.org/10.2478/mgrsd-2019-0009. 
CREŢAN, R., MATTHEWS, P. W. 2016: Popular responses to city-text changes: street naming and the politics of practicality in a post-socialist martyr city. Area, 48(1), 92-102. DOI: https://doi.org/10.1111/area.12241.

CRLJENKO, I. 2012: The renaming of streets and squares in post-Socialist Croatian towns. Language and Society, 3, 230-241.

DROZDZEWSKI, D. 2014: Using history in the streetscape to affirm geopolitics of memory. Political Geography, 42, 66-78. DOI: https://doi.org/10.1016/j.polgeo.2014.06.004.

ERÖSS, Á. 2017: Politics of street names and the reinvention of local heritage in the contested urban space of Oradea. Hungarian Geographical Bulletin, 66(4), 353-367. DOI: https://doi.org/10.15201/hungeobull.66.4.6.

GILL, G. 2005: Changing symbols: the renovation of Moscow place names. The Russian Review, 64(3), 480-503. DOI: https://doi.org/10.1111/j.1467-9434.2005.00371.x.

GIRAUT, F., HOUSSAY-HOLZSCHUCH, M. 2016: Place naming as dispositif: toward a theoretical framework. Geopolitics, 21(1), 1-21. DOI: http://dx.doi.org/10.1080/14650045. 2015.1134493.

GNATIUK, O. 2018: The renaming of streets in post-revolutionary Ukraine: regional strategies to construct a new national identity. AUC Geographica, 53(2), 119-136. DOI: https://doi.org/10.14712/23361980.2018.13.

GORDZIEJEW, J. 2017: Urbanonymic discourse in the post-Soviet Belarus. Acta BalticoSlavica, 41, 212-250. DOI: 10.11649/abs.2017.009. [ГАРДЗЕЯӮ, Ю. 2017: Урбананімічны дыскурс у постсавецкай Беларусі. Acta Baltico- Slavica, 41, 212-250].

KAPYLOU, I., LIPNITSKAYA, S. 2014: Current status and related problems of national toponyms standardization in the Republic of Belarus. Studia Białorutenistyczne, 8, 177-194.

KAZAKEVICH, A. 2011: Symbolism of place: forgetting and fragmentation of "Soviet" in the landscape of Minsk. An Immaculate Reserve: the Debates about Politics and Culture, 80(6), 17-33. [КАЗАКЕВИЧ А. 2011: Символика места: Забывание и фрагментация "советского" в ландшафте Минска. Неприкосновенный Запас: Дебаты о Политике и Культуре, 80(6), 17-33].

KOSTANSKI, L. 2009: “What's in a Name?" Place and Toponymic Attachment, Identity and Dependence. A Case Study of the Grampians (Gariwerd) National Park Name Restoration Process - Ph.D. thesis. Ballarat (University of Ballarat).

KOSTANSKI, L. 2016: Toponymic attachment. In C. Hough ed. The Oxford handbook of names and naming. Oxford (Oxford University Press), pp. 412-426. DOI: https://doi.org/10.1093/oxfordhb/9780199656431.013.42.

KOSTANSKI, L., PUZEY, G. 2014: A tale of two cities of literature: toponymic identity and the promotion of Edinburgh and Melbourne in the UNESCO Creative Cities Network. In Tort i Donada, J., Montagut i Montagut, M. eds. Els noms en la vida quotidiana: Actes del XXIV Congrés Internacional d'ICOS sobre Ciències Onomàstiques, vol. Annex, Secció 6. Barcelona (Departament de Cultura, Generalitat de Catalunya), pp. 1215-1224. DOI: https://doi.org/10.2436/15.8040.01.125.

LIGHT, D., NICOLAE, I., SUDITU, B. 2002: Toponymy and the communist city: street names in Bucharest, 1948-1965. GeoJournal, 56(2), 135-144. DOI: https://doi.org/ 10.1023/A:102246960.

LIGHT, D. 2004: Street names in Bucharest, 1990-1997: exploring the modern historical geographies of postsocialist change. Journal of Historical Geography, 30(1), 154-172. DOI: https://doi.org/10.1016/S0305-7488(02)00102-0.

LIGHT, D., YOUNG, C. 2014: Habit, memory, and the persistence of socialist-era street names in postsocialist Bucharest, Romania. Annals of the Association of American Geographers, 104(3), 668-685. DOI: https://doi.org/10.1080/00045608.2014.892377.

LIGHT, D., YOUNG, C. 2017: The politics of toponymic continuity: the limits of change and the ongoing lives of the street names. In Rose-Redwood, R., Alderman, D., Azaryahu, M. eds. The political life of urban streetscapes: naming, politics, and place. Abingdon and New York (Routledge), pp. 185-201.

LOSEV, А. F. 1993: Essays on antique symbolism and mythology. Moscow (Mysl'). [ЛОСЕВ А. Ф. 1993: Очерки античного символизма и мифологии. Москва (Мысль)]. 
LOTMAN, Yu. 2002: Articles about the semiotics of culture and art. St. Petersburg (Academic project). [Лотман Ю. М. 2002: Статьи по семиотике культуры и искусства. СанктПетербург (Академический проект)].

MARIN, A. 2012: Bordering time in the cityscape. Toponymic changes as temporal boundarymaking: street renaming in Leningrad/St. Petersburg. Geopolitics, 17(1), 192-216. DOI: https://doi.org/10.1080/14650045.2011.574652.

MÁCHA, P., LASSAK, H., KRTIČKA, L. 2018: City Divided: Place Names and Nationalism in the Czech-Polish Borderlands. Mitteilungen der Österreichischen Geographischen Gesellschaft - Annals of the Austrian Geographical Society, 160, 303-329. DOI: https://doi.org/10.1553/moegg160s303.

MINSK CITY AGENCY ON STATE REGISTRATION AND LAND CADASTRE 2019: Official street index of the City of Minsk. Official website of the Minsk City Agency on State Registration and Land Cadastre [cit. 2019-07-01]. Retrieved from: http://mga.by/catalog_streets.

MINSK CITY EXECUTIVE COMMITTEE 2019: About Minsk. Official website of the Minsk City Executive Committee [cit. 2019-07-01]. Retrieved from: https://minsk.gov.by/ $\mathrm{ru} /$ freepage/minsk/minsk/.

NATIONAL STATISTICAL COMMITTEE OF THE REPUBLIC OF BELARUS 2019: The Population of Belarus in the Regions on January 1, 2019. Official website of the National Statistical Committee of the Republic of Belarus [cit. 2019-07-01]. Retrieved from: http://www.belstat.gov.by/ofitsialnaya-statistika/ssrd-mvf_2/natsionalnaya-stranitsasvodnyh-dannyh/naselenie_6/chislennost-naseleniya1_yan_poobl/.

NIKOLAEV, I. V. 2013: Verbal symbols in the structure of political ideology. Politics and society, 12, 1499-1503. DOI: https://doi.org/10.7256/1812-8696.12.10348. [НИКОЛАЕВ И. В. 2013: Вербальные символы в структуре политической идеологии. Политика $u$ общество, 12, 1499-1503].

PALONEN, E. 2008: The city-text in post-communist Budapest: street names, memorials, and the politics of commemoration. GeoJournal, 73, 219-230. DOI: https://doi.org/10.1007/ s10708-008-9204-2.

POSPELOV, Ye. M. 1988: To the tourist about the geographical names. Moscow (Profizdat). [ПОЕСПЕЛОВ Е. М. 1988: Туристу о географических названиях. Москва (Профиздат)].

RAENTO, P., WATSON, C. J. 2000: Gernica, Guernica, Guernica? Contested meanings of a Basque place. Political Geography, 19 (6), 707-736. DOI: https://doi.org/10.1016/S09626298(00)00002-0.

RAJIĆ, L. 2012: Toponyms and the political and ethnic identity in Serbia. Oslo Studies in Language, 4(2), 203-222.

ROSE-REDWOOD, R., ALDERMAN, D., AZARYAHU, M. 2010: Geographies of toponymic inscription: new directions in critical place-name studies. Progress in Human Geography, 34(4), 453-470. DOI: https://doi.org/10.1177/0309132509351042.

ROSE-REDWOOD, R., ALDERMAN, D., AZARYAHU, M. 2017a: The urban streetscape as political cosmos. In Rose-Redwood, R., Alderman, D., Azaryahu, M. eds. The political life of urban streetscapes: naming, politics, and place. Abingdon and New York (Routledge), pp. 1-24.

ROSE-REDWOOD, R., ALDERMAN, D., AZARYAHU, M. 2017b: Contemporary issues and future horizons of critical urban toponymy. In Rose-Redwood, R., Alderman, D., Azaryahu, M. eds. The political life of urban streetscapes: naming, politics, and place. Abingdon and New York (Routledge), pp. 309-319.

ROSE-REDWOOD, R., VUOLTEENAHO, J., YOUNG, C., LIGHT, D. 2019: Naming rights, place branding, and the tumultuous cultural landscapes of neoliberal urbanism. Urban Geography, 40(6), 747-761. DOI: https://doi.org/10.1080/02723638.2019.1621125.

RYLIUK, G. Ya. 1999: The origins of the geographical names of Belarus (with the basics of general toponymy). Minsk (Vedy). [Рылюк, Г. Я. 1999: Истоки географических названий Беларуси (с основами общей топонимики). Минск (Веды)]. 
SAPAROV, A. 2003: The alteration of place names and construction of national identity in Soviet Armenia. Cahiers du Monde Russe, 44(1),179-198.

SAPAROV, A. 2017: Contested spaces: the use of place-names and symbolic landscape in the politics of identity and legitimacy in Azerbaijan. Central Asian Survey, 36(4), 534-554. DOI: https://doi.org/10.1080/02634937.2017.1350139.

SATSUKEVICH, I. 2010: The names of the streets and squares of Minsk as a historical and cultural heritage. Arche, 90(3), 324-341. [САЦУКЕВІЧ І. Назвы вуліц і плошчаў Мінска як гісторыка-культурная спадчына. Arche, 90(3), 324-341].

SATSUKEVICH, I. 2013: Toponymy of Mensk as a mirror of the historical politics of the authorities in 20 - early 21 centuries. Arche, 119(2), 239-254. [САЦУКЕВІЧ І. 2013: Тапаніміка Менска як люстэрка гістарычнай палітыкі ўладаў у XX - пачатку XXI стагоддзя. Arche, 119(2), 239-254].

SOKOLOVA, O. 2017: Minsk's text: the problems of cultural memory in the conditions of civilization's borderland. Minsk: Belarusian University of Culture and Arts. [СОКОЛОВА О. 2017: Минский текст: проблематика культурной памяти столичного города в условиях иивилизационного помежья. Минск: БГУКИ].

STIPERSKI, Z., LORBER, L., HERŠAK, E. et al. 2011: Identity through urban nomenclature: eight Central European cities. Geografisk Tidsskrift - Danish Journal of Geography, 111(2), 181-194. DOI: https://doi.org/10.1080/00167223.2011.10669532.

ŠAKAJA, L., STANIČ, E. 2011: Other(ing), self(portraying), negotiating: the spatial codification of values in Zagreb's city-text. Cultural Geographies, 18(4), 495-516. DOI: https://doi.org/10.1177/1474474011414636.

TITARENKO, L. 2008: Historical memory, embodied in the social space of Minsk, and its influence on the formation of national and European identities of Belarusians. Limes: Cultural Regionalistics, 1(1), 32-45. DOI: https://doi.org/10.3846/2029-0187.2008.1.32-45.

TITARENKO, L. 2011: Post-Soviet Belarus: the transformation of national identity. International Studies, 13(1), 11-21. DOI: https://doi.org/10.2478/v10223-011-0002-4.

VUOLTEENAHO, J., BERG, L. D. 2009: Towards critical toponymies. In Berg, L. D., Vuolteenaho, J. eds. Critical toponymies: the contested politics of place naming. Farnham (Ashgate), pp. 1-18.

VUOLTEENAHO, J., PUZEY, G. 2017: "Armed with an encyclopedia and axe": the socialist and post-socialist street toponymy of East Berlin revisited through Gramsci. In Rose-Redwood, R., Alderman, D., Azaryahu, M. eds. The political life of urban streetscapes: naming, politics, and place. Abingdon and New York (Routledge), pp. 74-97.

Acknowledgment: This article is an expanded and modified version of a paper presented at CAGONT-2017, The Canadian Association of Geographers - Ontario Division Annual Conference at Queen's University, Kingston, Ontario, Canada, October 20-21, 2017.

Authors' affiliations

College Prof. Sergei Basik, Ph. D.

Conestoga College Institute of Technology and Advanced Learning

School of Liberal Studies

299 Doon Valley Drive

Kitchener, Ontario, N2G 4M4

Canada

sergei.basik@gmail.com

Assoc. Prof. Dzmitry Rahautsou, Ph. D.

Mogilev State A. Kuleshov University

Department of Economics and Law

Kasmanautau Street 1

212022 Mahiliou

Republic of Belarus

drogov@tut.by 